Article

\title{
Analysis of Internal Gas Leaks in an MCFC System Package for an LNG-Fueled Ship
}

\author{
Gilltae Roh ${ }^{1,2}$, Youngseung Na ${ }^{3}$, Jun-Young Park ${ }^{4}\left(\mathbb{D}\right.$ and Hansung Kim ${ }^{2, *}$ \\ 1 Future Technology Research Team, Korean Register (KR), Busan 46762, Korea; gtroh@krs.co.kr \\ 2 Department of Chemical and Biomolecular Engineering, Yonsei University 134 Shinchon-Dong, \\ Seodaemun-gu, Seoul 120-749, Korea \\ 3 Department of Mechanical and Information Engineering, University of Seoul, Seoulsiripdaero 163, \\ Dongdaemun-gu, Seoul 02504, Korea; ysna@uos.ac.kr \\ 4 HMC, Department of Nanotechnology and Advanced Materials Engineering, Sejong University, \\ Seoul 143-747, Korea; jyoung@sejong.edu \\ * Correspondence: elchem@yonsei.ac.kr; Tel.: +82-2-2123-5753; Fax: +82-2-312-6401
}

Received: 19 April 2019; Accepted: 3 June 2019; Published: 6 June 2019

\begin{abstract}
The airflow inside the housing of a $300-\mathrm{kW}$ molten carbonate fuel cell (MCFC) system is designed to ensure safety in case of a gas leak by applying computational fluid dynamics (CFD) techniques. In particular, gas accumulating zones are identified to prevent damage to vulnerable components from high temperature and pressure. Furthermore, the location of the alarm unit with the gas-leak detector is recommended for construction of safe MCFC ships. In order to achieve this, a flow-tracking and contour field (for gas, temperature, and pressure) including a fuel-cell stack module, balance-of-plant, and various pipes is developed. With the simulated flow field, temperature flow is interpreted for the heating conditions of each component or pipe in order to find out where the temperature is concentrated inside the fuel cell system, as well as the increase in temperature at the exit. In addition, the gas leakage from the valves is investigated by using a flow simulation to analyze the gas and pressure distribution inside the fuel cell system.
\end{abstract}

Keywords: ship structure; LNG-fueled ship; green ship; numerical analysis; flow characteristics; molten carbonate fuel cell system

\section{Introduction}

The policies for marine environmental regulations of the International Maritime Organization (IMO) and governments have recently been strengthened to reduce air contaminants and greenhouse gases, including nitrogen oxides $\left(\mathrm{NO}_{\mathrm{x}}\right)$, sulfuric oxides $\left(\mathrm{SO}_{\mathrm{x}}\right)$, and carbon dioxide $\left(\mathrm{CO}_{2}\right)$. Marine engineers have therefore considered various strategies for building green ships such as developing a highly efficient propeller, modification of fan shapes, and optimization of an operational window [1-3]. In particular, in 2016, the IMO Marine Environment Protection Committee (MEPC) restricted the emissions of $\mathrm{SO}_{\mathrm{x}}$ from $3.5 \%$ to $0.5 \%$ for marine ships in the entire ocean until 2020 [4]. Today, many shipping firms are adopting liquefied natural gas (LNG) as marine fuel in an attempt to replace conventionally used heavy fuel oil (HFO). The use of LNG in ships is considered to be a way to safely use boil-off gas (BOG) that is naturally generated by heat leaks. As one option, the application of fuel cells to ships is being considered [5]. However, the ultimate goal of shipbuilders is to replace diesel engines, which emit greenhouse gases, with regenerative energy generators (zero-emission ships).

Energy storage systems (ESSs), and sunlight have received significant attention as environmentally friendly energy sources for green ships in the future [6]. Among these, fuel cells (FCs) have strong potential as an alternative to traditional marine propulsion power plants owing to their high efficiency, 
easy modularization, multi-fuel flexibility, and environmental friendliness [7]. In addition, FCs can essentially offer a silent and vibration-free operation, reducing the need for noise insulation of machinery. In particular, high-temperature molten carbonate fuel cells (MCFCs) have various advantages for green ships, because they achieve a system efficiency of more than $80 \%$, with negligible air-pollutant emissions when the waste heat is recovered. Furthermore, it may be economically efficient to use fuels such as LNG and liquefied hydrogen $\left(\mathrm{H}_{2}\right)$ carriers in gas-fueled and gas carriers, because MCFCs can use the BOG emitted from the LNG ship [8,9]. However, the development of green ships using fuel cells is still at a primitive stage, because of the considerable cost and time needed for construction of ships. Furthermore, liquefied gas carriers and gas-fueled ships may pose a high risk of explosion and fire from gas leaks, resulting from the localized damage (thermal expansion) of system components caused by high heat, because MCFCs are operated at a high temperature [10]. In addition, in order to use fuel cells in gas-fueled and gas carriers, severe weather and sea winds are considered among the design parameters needed to build a highly stable green ship with fuel cells.

In this regard, mathematical modeling plays an important role by significantly reducing the need for repetitive experiments and confirming concepts for building ships [11-13]. Moreover, several technical issues associated with the high operating temperature, such as explosion and fire caused by high heat, can be explored and thus mitigated through the new design and development progress for MCFC green ships. Ovrum and Dimopoulos (2012) [14] first reported the modeling work for an MCFC auxiliary power unit installed on board a vessel. They developed a modular dynamic model consisting of a set of partial differential and non-linear algebraic equations, employing 2D and 3D solid geometry and real gas properties to provide insight into the process dynamics and cell performance. Marra et al. [15] also presented the modeling approach as a tool for improving the current collector and gas distributor designs, optimizing MCFC performance with new technological solutions. This approach played a fundamental role in the thermal management of the MCFC, which is one of the most crucial points in performance improvements. However, there have been no reports of a safety study on the application of the MCFC system to a ship that comprehensively evaluates a computational fluid dynamics (CFD) analysis while considering intentional leakage simulation in the marine environment. Analysis of intentional leakage can indicate the design guidelines for a safe system and thus prevent potential damage.

Hence, to design highly efficient and stable MCFC green ships, we analyzed the characteristics (flows and distribution) of gas, heat, and pressure for the FC systems, e.g., stack, pipes, heat exchangers (HEXs) and balance-of-plant (BOP), by using the simulation tools referred to in the open literature. In particular, zones of localized high gas concentration, temperature, and pressure are identified, and design parameters needed to build safe MCFC ships, such as the location of the alarm unit with the gas leak detector and the capacity of exhaust fans, are recommended to prevent damage to system components from high heat and pressure. This study is expected to significantly contribute to the increased practical use of MCFCs in merchant marine applications.

Figure 1 is a schematic diagram of a fuel-cell system (BOP and stack) as an auxiliary power unit that can produce $300 \mathrm{~kW}$ of electricity by using the boil-off gas (BOG) of the LNG carrier. The BOG (as the fuel) generated from the LNG tank is fed to the pre-converter and anode side, and air (oxidant) is supplied from the cathode side to produce $300 \mathrm{~kW}$ of electricity through chemical and electrochemical reactions in the stack. The reactions are as follows:

$$
\begin{gathered}
\text { Anode }: \mathrm{H}_{2}+\mathrm{CO}_{3}^{2-} \leftrightarrow \mathrm{H}_{2} \mathrm{O}+\mathrm{CO}_{2}+2 \mathrm{e}^{-} \\
\mathrm{CO}+\mathrm{CO}_{3}^{2-} \leftrightarrow 2 \mathrm{CO}_{2}+2 \mathrm{e}^{-} \\
\mathrm{CH}_{4}+\mathrm{H}_{2} \mathrm{O} \leftrightarrow \mathrm{CO}+3 \mathrm{H}_{2} \\
\mathrm{CO}+\mathrm{H}_{2} \mathrm{O} \leftrightarrow \mathrm{CO}_{2}+\mathrm{H}_{2} \\
\text { Cathode }: \mathrm{CO}_{2}+\frac{1}{2} \mathrm{O}^{2}+2 \mathrm{e}^{-} \leftrightarrow \mathrm{CO}_{3}^{2-}
\end{gathered}
$$




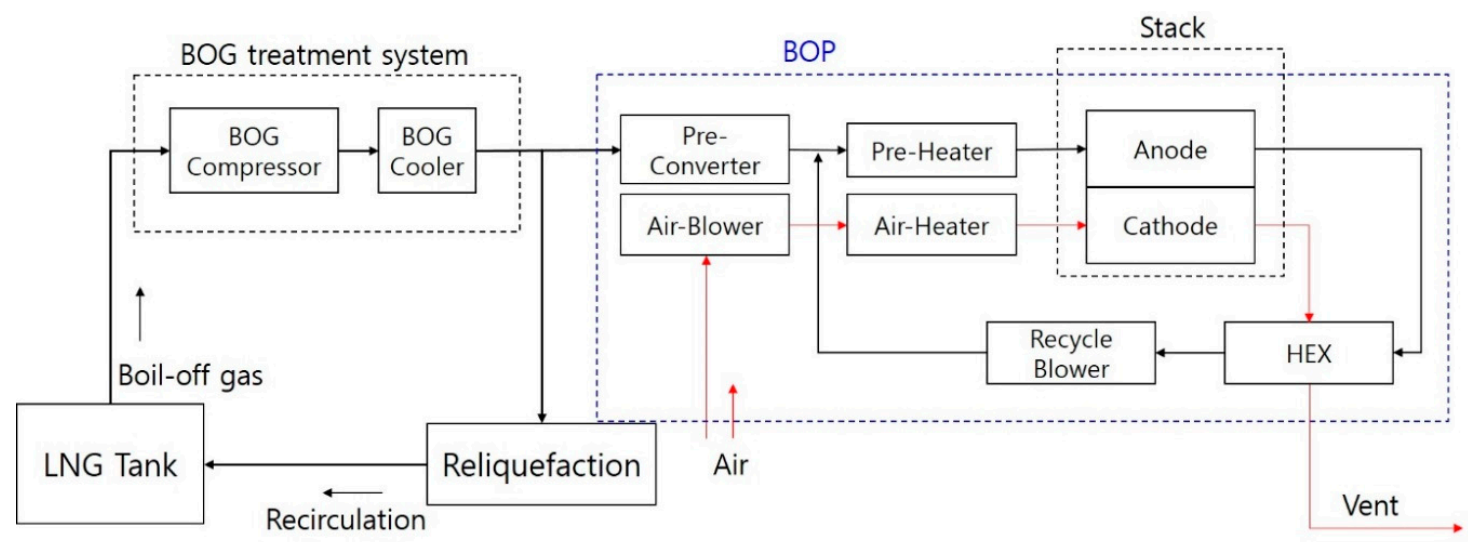

Figure 1. Scheme of boil-off gas (BOG) treatment system with fuel cell system for a liquefied natural gas (LNG)-fueled ship.

In this study, the characteristics of flow inside the 300-kW fuel-cell system was analyzed using CFD. To prevent gas leaks from inside the BOP, it is very important to identify the status of internal air flow and to find an appropriate location for installing the equipment for gas detection.

\section{CFD Simulation Method}

\subsection{Modeling and Boundary Conditions}

Figure 2 shows a 3D CAD model of the components inside the BOP, which is designed to operate the 300-kW MCFC stack. Inside the BOP is a pretreatment device used to provide fuel to the anode and oxidant to the cathode. The anode side of the BOP includes the pre-converter, polisher, humidifier, recycle blower, etc. The pre-converter converts the methane from the BOG to about $10 \%$ hydrogen to supply to the stack. The humidifier produces steam, which is supplied to the anode side of the stack for the electrochemical reaction in the stack. The polisher and recycle blower recirculate the exhaust gas at the end of the stack.

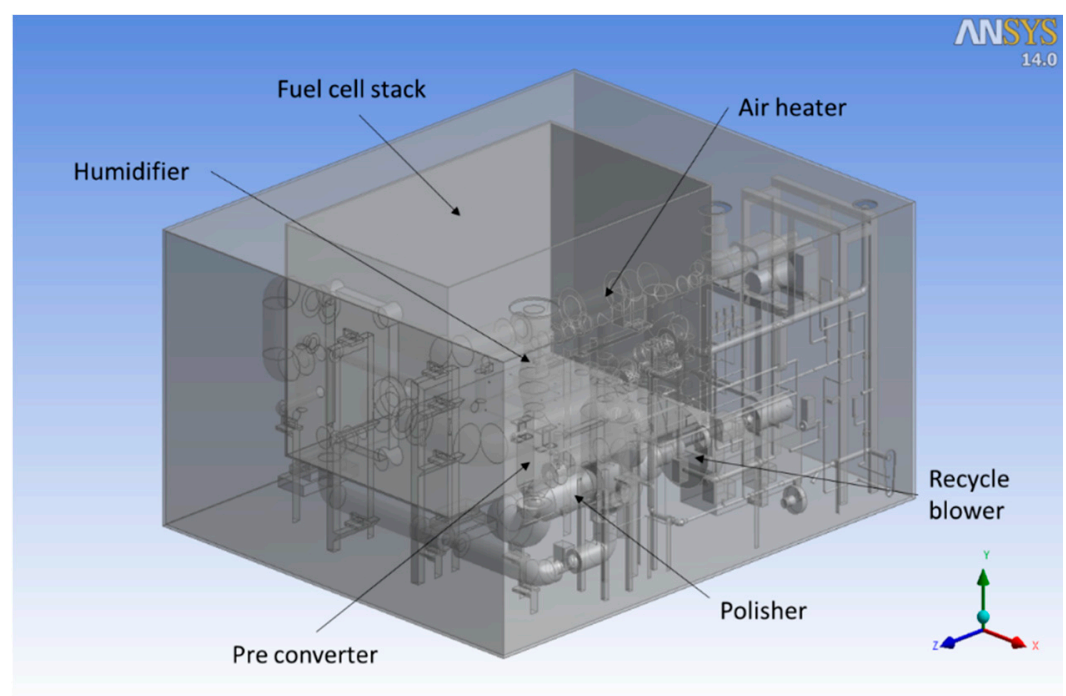

Figure 2. Component locations in a molten carbonate fuel cell (MCFC) stack package.

The grid system of the package (without the external components) was created using the ANSYS Design Modeler [16] and ICEM-CFD [17]. An unstructured tetrahedron grid technique was efficiently applied to create the overall grid system. The grid cells with a prism shape were applied near a specific solid wall to resolve the relatively high velocity gradient. The uniform thickness ratios were maintained 
for the grid cell layers with different unit cells. Thus, in this analysis, approximately 20 million grid cells were used. The solution was independent from computational cell numbers.

The louvers on the outer walls of the package room shown in Figure 3a were installed to assist in supplying air to the inside of the room to cool the equipment. The blue parts of the figure indicate the points where air is supplied to the room. The room air was set to atmospheric pressure and an ambient temperature of $25^{\circ} \mathrm{C}$. As shown in Figure 3b, the air heated by the devices inside the package was released through the exhaust fans installed on the roof. As shown in Figure 3b, in order to release the air at a speed of $10.3 \mathrm{~m} \cdot \mathrm{s}^{-1}$ through each exhaust pipe, the performance of the applied exhaust fan was $5000 \mathrm{~m}^{3} \cdot \mathrm{h}^{-1}$ and the cross-sectional area of the exhaust pipes was $0.135 \mathrm{~m}^{2}$. The heating surface (shown in blue in Figure 2) was set according to the specific heat fluxes for the heating area shown in Table 1. Since the package room is exposed to the outside, heat is transferred through the walls according to the surroundings; and the heat-transfer coefficient was set as $100 \mathrm{~W} \cdot \mathrm{m}^{-2} \mathrm{~K}^{-1}$ to simulate the convective heat transfer of a weak wind. To identify the leakage in the system, fuel was modeled as leaked intentionally at the red points in Figure 4 with listed gas composition in Table 2. The leaked gas path line is traced by the CFD, and provides the supporting data to locate gas leak detectors.
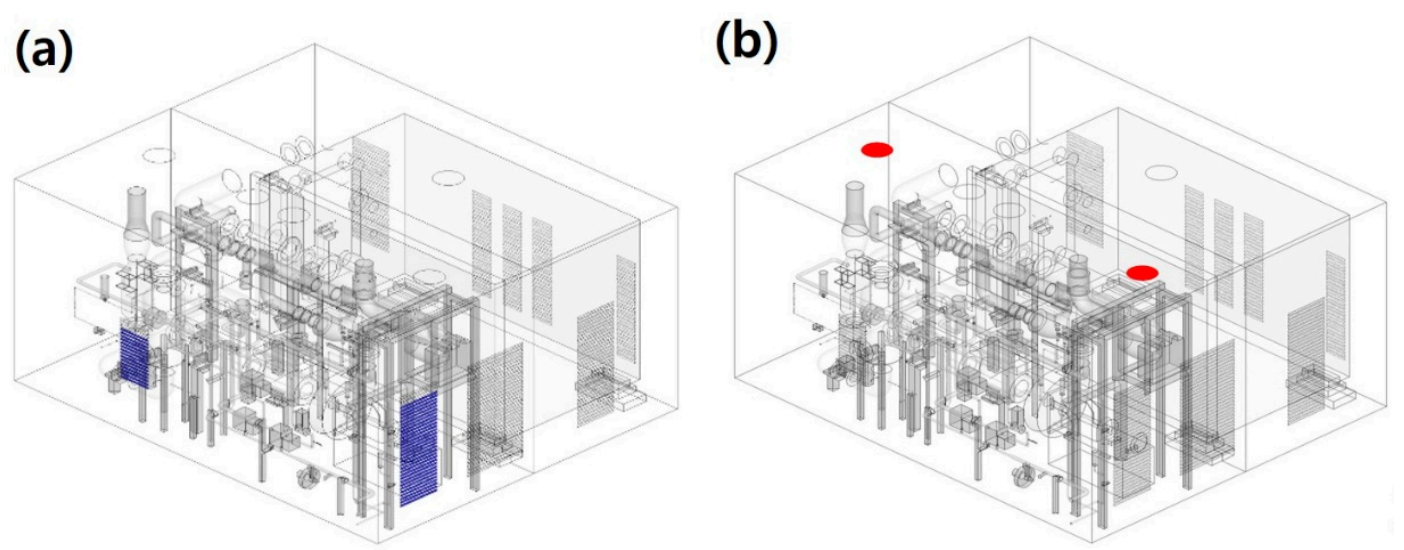

Figure 3. Conditions of the inlet and outlet of the balance-of-plant (BOP) package: (a) louver installation locations (inlet) and (b) exhaust pipe locations (outlet).

Table 1. Heat flux of the heating area of the stack package model.

\begin{tabular}{|c|c|c|c|c|}
\hline & Area $\left[\mathrm{m}^{2}\right]$ & Total Heating Area $\left[\mathrm{m}^{2}\right]$ & Heat Value [kW] & Heat Flux $\left[W / \mathrm{m}^{2}\right]$ \\
\hline Humidifier & 1.189 & \multirow{2}{*}{1.515} & \multirow{2}{*}{1.00} & \multirow{2}{*}{660.1} \\
\hline EG-2012 & 0.326 & & & \\
\hline Polisher & 1.134 & \multirow{2}{*}{2.651} & \multirow{2}{*}{2.426} & \multirow{2}{*}{915.1} \\
\hline EG-2011 & 1.517 & & & \\
\hline EG-2010 & 7.281 & 7.281 & 4.00 & 549.3 \\
\hline Pre-converter & 2.507 & \multirow{3}{*}{8.368} & \multirow{3}{*}{2.00} & \multirow{3}{*}{239.0} \\
\hline FG-2008 & 1.959 & & & \\
\hline FG-2009 & 3.902 & & & \\
\hline Recycle blower & 1.865 & \multirow{4}{*}{9.537} & \multirow{4}{*}{1.68} & \multirow{4}{*}{176.2} \\
\hline EG-4008 & 1.484 & & & \\
\hline EG-4009 & 5.689 & & & \\
\hline Air heater & 0.499 & & & \\
\hline Stack module & 53.111 & 53.111 & 9.00 & 169.5 \\
\hline
\end{tabular}




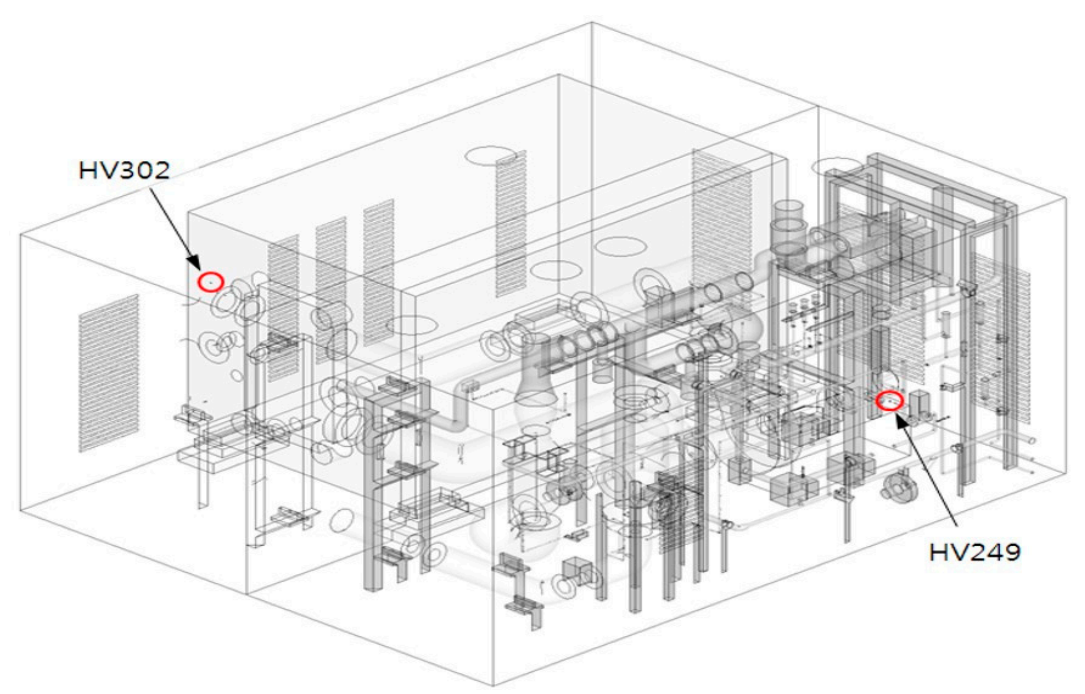

Figure 4. Leaked valve positions in the MCFC stack package.

Table 2. Leaked gas composition.

\begin{tabular}{ccccc}
\hline & \multicolumn{2}{c}{ HV249 } & \multicolumn{2}{c}{ HV302 } \\
\cline { 2 - 5 } & Mole Fraction & Mass Fraction & Mole Fraction & Mass Fraction \\
\hline $\mathbf{C H}_{\mathbf{4}}$ & 0.938 & 0.8934 & 0.1498 & 0.1751 \\
\hline $\mathbf{H}_{\mathbf{2}} \mathbf{O}$ & 1.134 & 2.651 & 0.3196 & 0.4196 \\
\hline $\mathbf{H}_{\mathbf{2}}$ & - & - & 0.4127 & 0.0606 \\
\hline $\mathrm{CO}_{\mathbf{2}}$ & - & - & 0.0874 & 0.2803 \\
\hline Air & 0.062 & 0.1066 & 0.0305 & 0.0644 \\
\hline
\end{tabular}

\subsection{Governing Equations}

The governing equations of mass, momentum, turbulence, and heat transfer were applied in accordance with the buoyancy effect in the internal airflow simulation. In Reynolds averaging, the velocity vector $\mathbf{v}$ is decomposed into the mean and fluctuating velocity components as $\mathbf{v}=\overline{\mathbf{v}}+\mathbf{v}$ ' Likewise, a scalar, $\phi$ (such as pressure, energy, and other quantities) is decomposed as $\phi=\bar{\phi}+\phi^{\prime}$. The incompressible Reynolds-averaged Navier-Stokes (RANS) equations are defined as follows [18]:

$$
\begin{gathered}
\frac{\partial \rho}{\partial t}+\nabla \cdot(\rho \overline{\mathbf{v}})=0 \\
\frac{\partial}{\partial t}(\rho \overline{\mathbf{v}})+\nabla \cdot(\rho \overline{\mathbf{v}})=-\nabla \bar{p}+\nabla \cdot\left(2 \mu \overline{\mathbf{s}}-\rho \overline{\mathbf{v} / \mathbf{v}^{\prime}}\right)+\rho \mathrm{g}
\end{gathered}
$$

where $\rho$ is the density calculated from the ideal gas equation of state, $t$ is time, $\bar{p}$ is the mean pressure, $\mu$ is the molecular viscosity and $\overline{\mathbf{s}}=\frac{1}{2}\left(\nabla \overline{\mathbf{v}}+\nabla \overline{\mathbf{v}}^{T}\right)$ is the mean strain-rate tensor. The quantity $-\rho \overline{\mathbf{v} \prime \mathbf{v}^{\prime}}$ is defined as the Reynolds stress tensor, and $\rho \mathrm{g}$ is the gravitational body force. To close the RANS equations, the Reynolds stress tensor is modeled on the basis of the Boussinesq approximation as follows:

$$
\rho \overline{\mathbf{v} \prime \mathbf{v} \prime}=2 \mu_{t} \overline{\mathbf{s}}-\frac{2}{3} \rho K \mathbf{I}
$$

where $\mu_{t}$ is the turbulent viscosity, the turbulent kinetic energy is defined as $K=\frac{1}{2} \overline{\mathbf{v}^{\prime} \mathbf{v} \mathbf{\prime}}$, and $\mathbf{I}$ is the unit tensor. 
Turbulent kinetic energy $K$ and turbulence dissipation rate $\varepsilon$ for the turbulence model were calculated using Equations (9) and (10) [18].

$$
\begin{gathered}
\frac{\partial(\rho K)}{\partial t}+\nabla \cdot(\rho \mathbf{v} K)=\nabla \cdot\left[\left(\mu+\frac{\mu_{t}}{\operatorname{Pr}_{k}}\right) \nabla K\right]+P_{k}-\rho \varepsilon \\
\frac{\partial(\rho \varepsilon)}{\partial t}+\nabla \cdot(\rho \mathbf{v} \varepsilon)=\nabla \cdot\left[\left(\mu+\frac{\mu_{t}}{\operatorname{Pr}_{\varepsilon}}\right) \nabla \varepsilon\right]+\frac{\varepsilon}{k}\left(C_{\varepsilon 1} P_{k}-C_{\varepsilon 2} \rho \varepsilon\right)
\end{gathered}
$$

where $P_{k}$ is the generation of turbulent kinetic energy caused by the mean velocity gradients and buoyancy, $C_{\varepsilon 1}$ and $C_{\varepsilon 2}$ are the model constants, and $\operatorname{Pr}_{k}$ and $\operatorname{Pr}_{\varepsilon}$ are the turbulent Prandtl numbers for $K$ and $\varepsilon$, respectively. Here, the turbulent viscosity $\mu_{t}$ is calculated by combining $K$ and $\varepsilon$ as $\mu_{t}=\rho C_{\mu} \frac{K^{2}}{\varepsilon}$, where $C_{\mu}$ is a constant.

The energy equation is modeled using the concept of the Reynolds analogy to turbulent momentum transfer:

$$
\frac{\partial}{\partial t}\left(\rho C_{p} \bar{T}\right)+\nabla \cdot\left(\rho C_{p} \overline{\mathbf{v}} \bar{T}\right)=\nabla \cdot\left[k \nabla T-\rho C_{p} \overline{\mathbf{v} \prime T^{\prime}}\right]+S_{T}
$$

where $C_{p}$ is the heat capacity, $T$ is the temperature, and $k$ is the molecular thermal conductivity. The turbulent thermal conductivity is calculated as $k_{t}=\mu_{t} \frac{C_{p}}{\operatorname{Pr}_{t}}$, in which $\operatorname{Pr}_{t}$ is the turbulent Prandtl number. The $\rho C_{p} \overline{\mathbf{v} / T^{\prime}}$ term is defined as $k_{t} \nabla T$ and the source term $S_{T}$ includes a volumetric heat source.

\section{Results and Discussion}

\subsection{Concentration Distribution}

Methane was assumed to be leaked from the HV249 and HV302 valves. The gas from HV249 diffused throughout the entire chamber. The volume fraction of methane was plotted from 0 to $5 \%$, which is the lower limit to explode, as shown in Figure 5a. Near HV302, methane was located at the point because of the small composition in the leaked gas. The iso-surface of the methane volume fraction of $2 \%$ covered around one quarter of the BOP chamber, which should be ventilated by carrier gas from the louver on the right-hand side in Figure $5 b$. Therefore, the gas detector should be located on the ceiling, and the evacuating jet fan should operate in an emergency to suck flammable gas from the chamber.

\section{(a)}

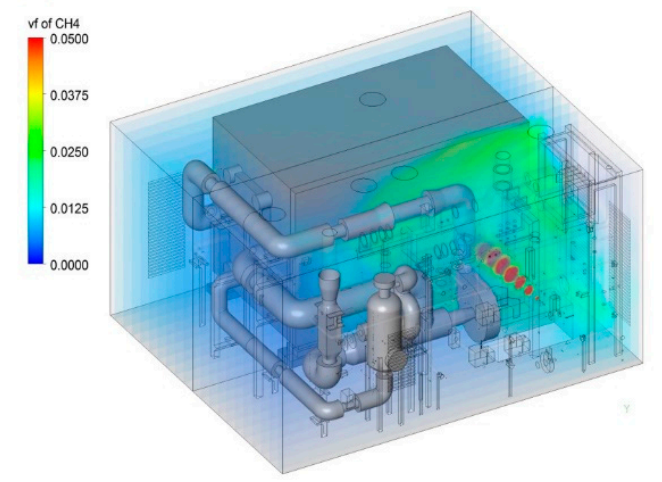

(b)

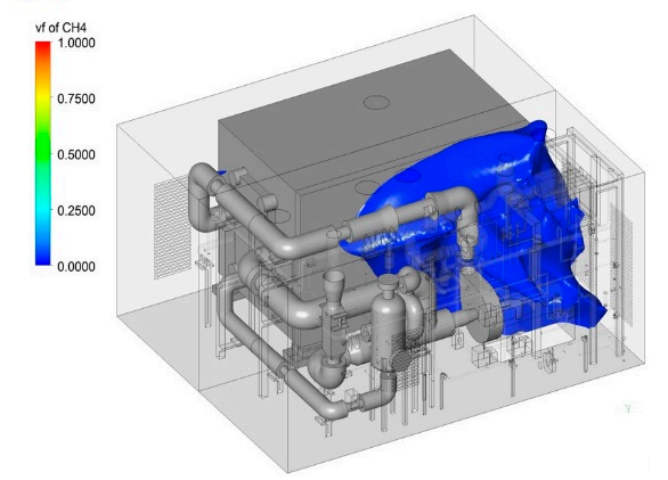

Figure 5. (a) Volume fraction distribution and (b) 2\% iso-surface of leaked methane inside the MCFC stack package.

In contrast, hydrogen leakage from HV302 differed from the methane distribution. The average hydrogen concentration was much lower than that of methane and it quickly diffused to the whole 
chamber, as shown in Figure 6a,b. The low concentration of $1 \%$ which accumulated behind the stack because of stagnant flow is not dangerous, but it must be circulated by a blowing or suction fan.

(a)

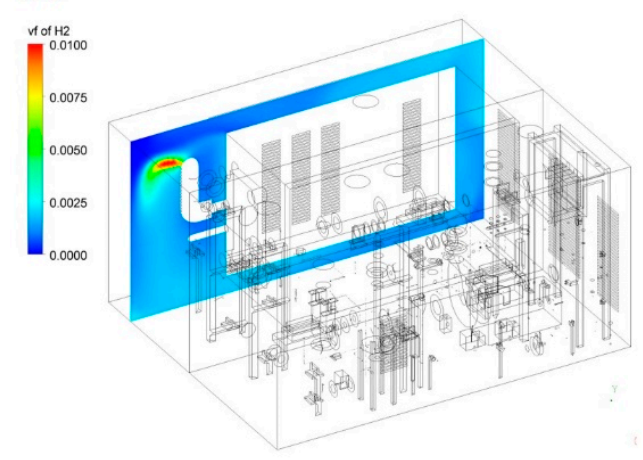

(b)

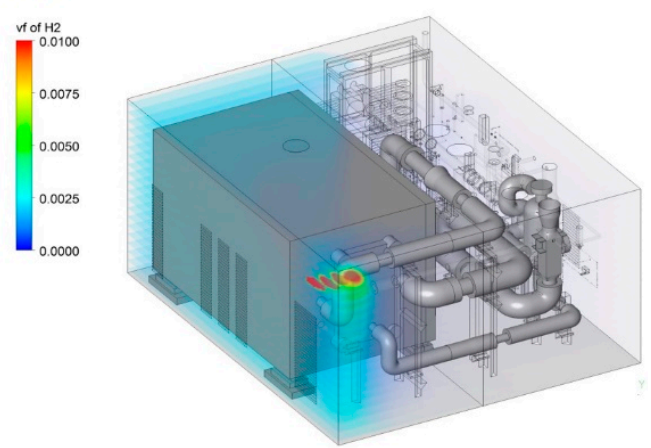

Figure 6. (a) One vertical section and (b) horizontal sections of the volume fraction of leaked hydrogen inside the MCFC stack package.

\subsection{Flow Fields}

Figure 7 shows the velocity vectors of the vertical sections of inlet and outlet flow. Inlet gas from the louvers on the right-hand side flowed to the holes on the ceiling, as shown in Figure 7. The average speed from the louvers was $4.2 \mathrm{~m} \cdot \mathrm{s}^{-1}$, whereas the whole range covered from zero to $5 \mathrm{~m} \cdot \mathrm{s}^{-1}$. The red spot in the chamber observed near HV249 indicates leaked jet flow. The left-hand side louvers on the front panel blew at an average speed of $3.8 \mathrm{~m} \cdot \mathrm{s}^{-1}$, which was lower than the right-hand side because of the structure. The wing side of the louvers was positioned at $45^{\circ}$ towards the internal side of the package, and the path lines formed in this direction passed through the louvers. The colors of the path lines in the figure represent the temperature distribution, showing that the temperature of the cables passing through the internal components had increased.

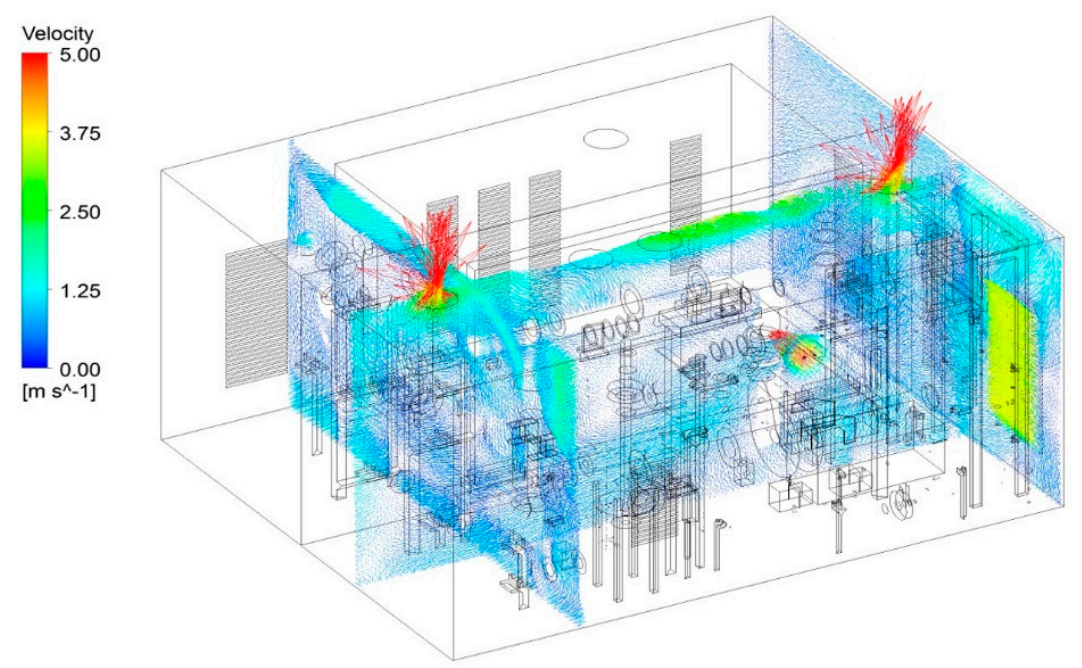

Figure 7. Velocity vectors of the MCFC stack package.

Path lines from the right-hand side louvers scattered rigorously to the outside and carried methane from the chamber in Figure 8a,b. In contrast, the left-hand side flow field has a few path lines with high temperature, because of the stagnant flow near the stack. Even though the concentration of hydrogen is less than the lower limit for an explosion, circulating flow is necessary to flush out the flammable gas from the chamber. 
(a)

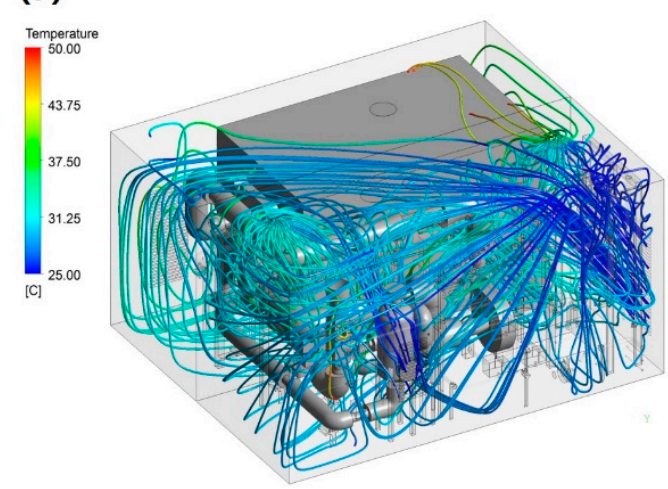

(b)

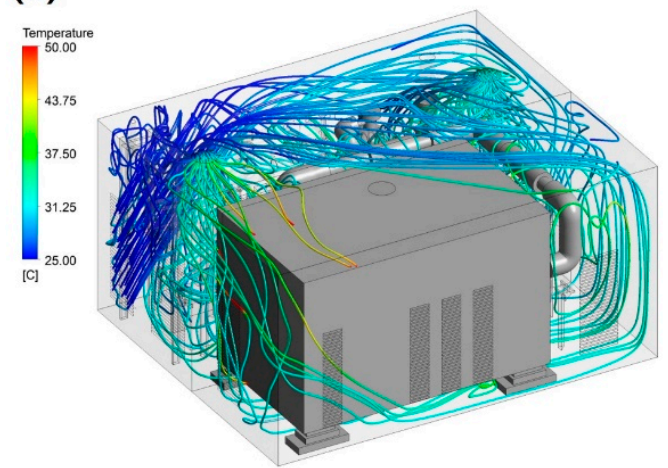

Figure 8. Path lines of inlet flows from louvers and outlet flows to the exit holes on the ceiling (a) frontal view and (b) backside view.

\subsection{Temperature Fields}

The skin temperature of the polisher and humidifier components, from the ambient temperature to the highest temperature of $200^{\circ} \mathrm{C}$, is shown in Figure $9 \mathrm{a}, \mathrm{b}$ and indicates that the air temperature distribution in the vertical sections of the chamber was not uniform, despite the cooling air from the louvers. Because the BOP package is in contact with internal heat, the air temperature in the upper part of the package is a result of the influence of the increased density and upward flow of the exhaust air. In particular, the temperature of the upper side of the fuel cell stack was as high as that of the polisher because of accumulating flow, which relates to the flow field. Additionally, the hot leaked flow from the HV302 was stagnant near the stack. The average outlet temperature of the two exit holes was about $31.5^{\circ} \mathrm{C}$.

(a)

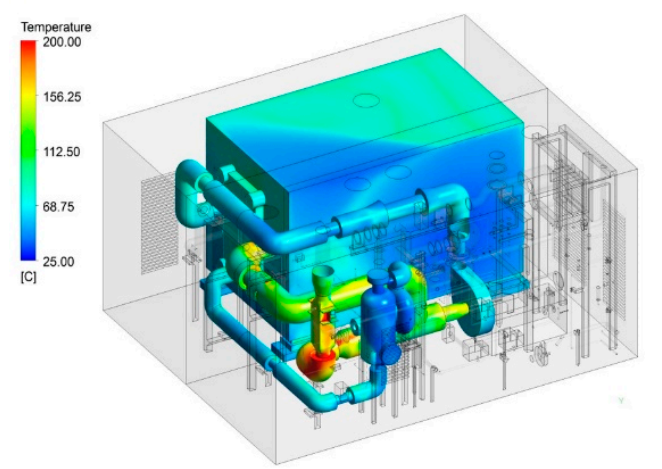

(b)

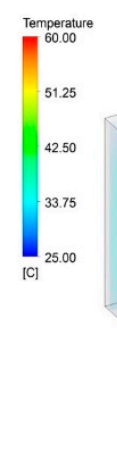

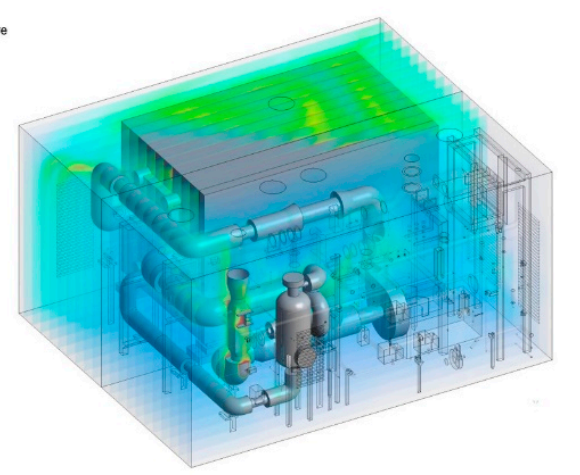

Figure 9. Temperature distribution of the MCFC stack package at outer temperature $25^{\circ} \mathrm{C}$ : (a) surface temperature at heating pipe and (b) yz plane.

\subsection{Pressure Fields}

Figure 10 shows the vertical section of pressure distribution inside the package. The range of pressure was shown to be 101,313-101,320 Pa, and it was observed that low pressure was caused by the velocity increment near the exhaust pipe region, which lead to a static pressure drop. However, it can be concluded that the pressure differences inside the package were relatively insignificant. 


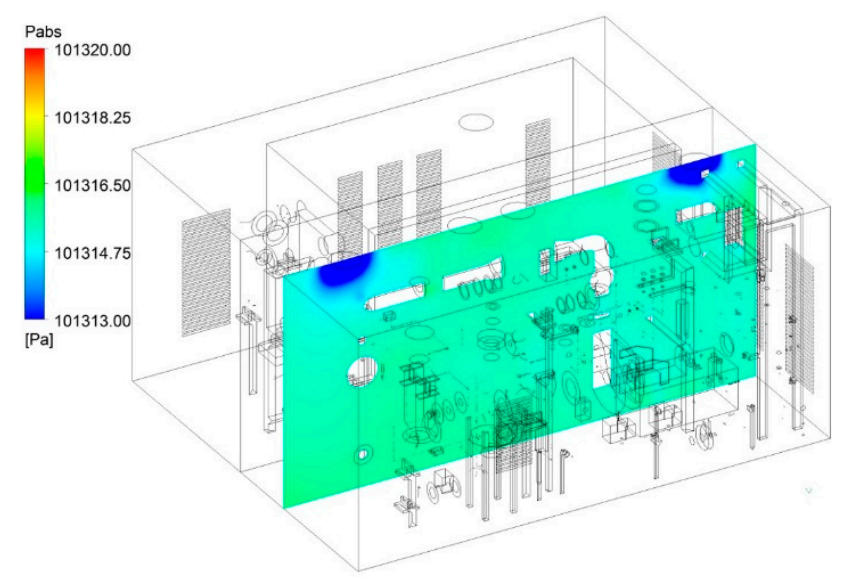

Figure 10. Pressure distribution at vertical section inside the MCFC stack package at $25^{\circ} \mathrm{C}$.

\section{Conclusions}

The flow characteristics inside a fuel cell balance-of-plant (BOP) package were analyzed through computational fluid dynamics (CFD) techniques. The simulation was used to interpret the characteristics of gas, pressure, and temperature flows according to chemical species. The developed model indicated that the inside flow structure plays an important role not only in heating the internal units, but also in the distribution and emission of the leaked gas. In addition, the heat flow was confirmed to be controlled, excluding the entrance and exit of the stack module. However, the flow field through the stack module, the outer walls of the package, and the top of the module were not cooled to the ambient temperature. Moreover, temperature increases were observed at the rear side of the stack module, in the stagnant area at the top of the stack module, and within the leaked gas accumulated in these areas. Therefore, the density distribution can be decreased by lowering the temperature inside the package and quickly venting the leaked gas. The capacity to supply external air should thus be designed by generating a smooth flow between the stack module and the outer walls of the package.

The interpretation of the 300-kW MCFC BOP package model shows that the flow of air generated inside the package and the surface temperature of the heating apparatus influenced the flow of heat and air in the package. In other words, if the heat generated is higher than that of the exothermic device, the temperature of the surface of the heated ventilation system would need to be kept at less than the ambient temperature. In this case, the design of the airflow inside the device is important for preventing an increase in the temperature of the internal device.

The simulation of gas leakage and fuel gas density in the BOP package has indicated that the natural gas line should be ventilated to the outside of the chamber because methane diffused in all directions throughout the whole chamber, whereas the hydrogen gas flowed directly upwards. Therefore, the safety ventilation outlet should be located with the gas alarm on the ceiling near the hydrogen pipeline. For maximum safety, the ventilation and alarm systems should be designed according to the simulated flow field.

Author Contributions: G.R. wrote the manuscript, conceptualized, and analyzed; Y.N. and J.-Y.P. analyzed and validated results; and H.K. supervised.

Funding: This material is based upon work supported by the Ministry of Trade, Industry \& Energy (MOTIE, KOREA) under industrial Core technology Development Program. NO. 10070159, 'Development of CCS technologies (design and verification) to apply $\mathrm{LH}_{2}$ Carrier.'

Conflicts of Interest: The authors declare no conflict of interest. 


\section{References}

1. Boswinkel, H.H. Ship Propulsion with Fuel Cells, ECN-C-91-022; ECN: Rotterdam, The Netherlands, 1991.

2. Buhaug, Ø.; Corbett, J.; Endresen, Ø.; Eyring, V.; Faber, J.; Hanayama, S.; Lee, D.; Lee, D.; Lindstad, H.; Markowska, A. Second IMO GHG Study 2009; International Maritime Organization (IMO): London, UK, 2009; p. 20.

3. Sattler, G. Fuel cells going on-board. J. Power Sources 2000, 86, 61-67. [CrossRef]

4. The 70th Session of the Marine Environment Protection Committee. Amendments to the annex of the protocol of 1997 to amend the international convention of plooution from ships, 1973, as modified by the protocol of 1978 relating thereto. In Proceedings "Resolution MEPC.278(70)"; IMO: London, UK, 2016.

5. De-Troya, J.J.; Álvarez, C.; Fernández-Garrido, C.; Carral, L. Analysing the possibilities of using fuel cells in ships. Int. J. Hydrog. Energy 2016, 41, 2853-2866. [CrossRef]

6. Lan, H.; Bai, Y.; Wen, S.; Yu, D.; Hong, Y.Y.; Dai, J.; Cheng, P. Modeling and stability analysis of hybrid $\mathrm{PV} /$ diesel/ESS in ship power system. Inventions 2016, 1, 5. [CrossRef]

7. Sundmacher, K. Molten Carbonate Fuel Cells: Modeling, Analysis, Simulation, and Control; Wiley-VCH: Weinheim, Germany, 2007; pp. 519-932.

8. Lee, J.H.; Kim, Y.J.; Hwang, S. Computational study of LNG evaporation and heat diffusion through a LNG cargo tank membrane. Ocean Eng. 2015, 106, 77-86. [CrossRef]

9. Roh, S.; Son, G.; Song, G.; Bae, J. Numerical study of transient natural convection in a pressurized LNG storage tank. Appl. Therm. Eng. 2013, 52, 209-220. [CrossRef]

10. Ling-Chin, J.; Roskilly, A.P. Investigating the implications of a new-build hybrid power system for Roll-on/Roll-off cargo ships from a sustainability perspective-A life cycle assessment case study. Appl. Energy 2016, 181, 416-434. [CrossRef]

11. Lataire, E.; Vantorre, M.; Delefortrie, G.; Candries, M. Mathematical modelling of forces acting on ships during lightering operations. Ocean Eng. 2012, 55, 101-115. [CrossRef]

12. Wang, X.G.; Zou, Z.J.; Hou, X.R.; Feng, X. System identification modelling of ship manoeuvring motion based on support vector regression. J. Hydrodyn. Ser. B 2015, 27, 502-512. [CrossRef]

13. Welaya, Y.M.; El Gohary, M.M.; Ammar, N.R. A comparison between fuel cells and other alternatives for marine electric power generation. Int. J. Nav. Archit. Ocean Eng. 2011, 3, 141-149. [CrossRef]

14. Ovrum, E.; Dimopoulos, G. A validated dynamic model of the first marine molten carbonate fuel cell. Appl. Therm. Eng. 2012, 35, 15-28. [CrossRef]

15. Wang, K.; Hissel, D.; Péra, M.; Steiner, N.; Marra, D.; Sorrentino, M.; Pianese, C.; Monteverde, M.; Cardone, P.; Saarinen, J. A review on solid oxide fuel cell models. Int. J. Hydrog. Energy 2011, 36, 7212-7228. [CrossRef]

16. Atmaca, M.; Girgin, İ.; Ezgi, C. CFD modeling of a diesel evaporator used in fuel cell systems. Int. J. Hydrog. Energy 2016, 41, 6004-6012. [CrossRef]

17. Fluent, A. 12.0 Theory Guide; Ansys Inc.: Pittsburgh, PA, USA, 2009; Volume 5.

18. Wilcox, D.C. Turbulence Modeling for CFD, 2nd ed.; DCW Industries: La Cañada Flintridge, CA, USA, 2004; pp. 35-36, 123-125.

(C) 2019 by the authors. Licensee MDPI, Basel, Switzerland. This article is an open access article distributed under the terms and conditions of the Creative Commons Attribution (CC BY) license (http://creativecommons.org/licenses/by/4.0/). 